\title{
Washington Insider: Overview of FY18 Funding Status and APSA Advocacy
}

\author{
Abby Paulson, APSA Program Coordinator, Government Relations and Public Engagement
}

S ince October 2017, the federal government has relied on stopgap funding measures that maintain government agencies at roughly FY17 funding levels until the FY18 appropriations are finalized in Congress. The House of Representatives passed an omnibus $\mathrm{FY} 18$ appropriations bill (H.R. 3354) before the end of the 2017 fiscal year. At the time of this writing, the Senate has only passed some funding bills through committee and has not provided a timeline for bringing the bills to the floor.

The FY18 presidential budget request included several provisions harmful to political science. The proposals, which were largely rejected by appropriations committees, included the elimination of funding for the National Endowment for the Humanities, end of Title VI and Fulbright-Hays programs, and a $10 \%$ reduction to National Science Foundation funding. Of these proposals, only the elimination of Fulbright-Hays is represented in Congress' appropriations bills.

The National Science Foundation largely maintains bipartisan support in Congress but still faces small cuts to accommodate budget caps. The Senate
Appropriations Committee approved the Commerce, Justice, and Science appropriations legislation (S.1662) in July. The bill allocates the NSF \$7.31 billion for FY18, a $2.2 \%$ overall decrease from the preceding fiscal year. The Senate bill includes a 1.9\% cut to funding for research and related activities. In contrast, the House's corresponding legislation (H.R.3276) holds flat the NSF's budget for research, which is also reflected in the final House omnibus bill.

The House appropriations bill for the National Endowment for the Humanities (H.R. 3354) provides \$145 million to the agency. The appropriation is approximately \$5 million below the FY17 funding level, but rejects the administration's request to begin the process of shutting down the agency. The Senate bill has yet to be marked up by committee but proposes approximately $\$ 150$ million, equal to enacted $\mathrm{FY}_{17}$ funding levels.

The international education programs at the Department of Education face challenges in the House of Representatives for both the appropriation and authorization of future funding. The House's appropriations bill (H.R.3358) does not include funding for Fulbright-Hays but provides

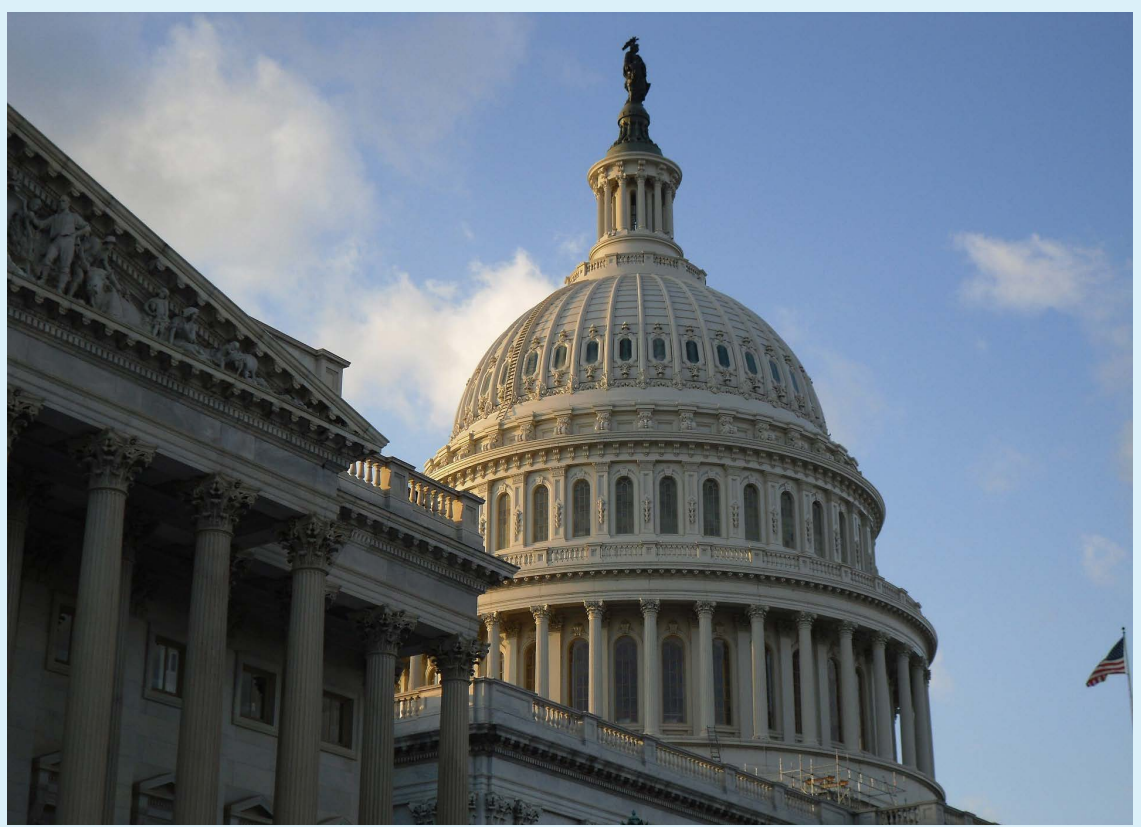

flat funding for Title VI programs. The Senate passed out of committee S.1771, which includes flat funding for both programs.

The reauthorization of the Higher Education Act, which sets authorized funding levels for international education programs, was launched at the end of 2017 with the introduction of several pieces of competing legislation. In the House, Republicans and Democrats have introduced separate authorizing bills (H.R.4508 and H.R.4491, respectively). The Republicans' PROSPER Act (H.R.4508) makes significant changes to Title VI programs. The bill would eliminate four unfunded programs and two funded programs, including Undergraduate International Studies and Foreign Languages and the American Overseas Research Centers, and maintain five Title VI programs. The authorization, which would extend to 2024, would be limited to approximately $\$ 61.5$ million. The level is roughly equal to the total FY17 funding for the five continued programs. The House Democratic bill (H.R.4491) and bipartisan Senate legislation (S.2255) maintain funding for all currently authorized Title VI programs.

In addition to APSA's regular advocacy on federal funding for political science research, the association also addressed issues present in tax reform legislation that would have been deeply harmful to the political science discipline and graduate education at large. The original version of the House's Tax Cuts and Jobs Act (H.R.1) removed a provision from the existing tax code that excluded tuition waivers from taxation. APSA shared action alerts with members through the newsletter and social media. The problematic provision was not included in the final bill.

For up-to-date information about the status of federal funding for political science research and education, opportunities for members to participate in advocacy efforts, and responses to proposed budgets and legislation, visit www.apsanet. org/advocacy. 